\title{
Anti-CA19-9 Monoclonal Antibody 5B1
}

National Cancer Institute

\section{Source}

National Cancer Institute. Anti-CA19-9 Monoclonal Antibody 5B1. NCI Thesaurus. Code C125900.

A human monoclonal antibody against the carbohydrate antigen sialyl-Lewis A (carbohydrate antigen 19-9; CA19-9), with potential antineoplastic activity. Upon administration, monoclonal antibody 5B1 binds to CA19-9 and kills CA19-9-expressing tumor cells, possibly through the induction of both complement-dependent cytotoxicity (CDC) and antibody-dependent cell-mediated cytotoxicity (ADCC). CA19-9 is overexpressed on a number of different tumor cell types, and plays a key role in tumor cell survival and metastasis. 